\title{
Inheritance Model-Based Character Values of Local Wisdom
}

\author{
Nurhamzah \\ Faculty of Tarbiyah and Teacher Training \\ UIN Sunan Gunung Djati \\ Bandung, Indonesia \\ nurhamzah@uinsgd.ac.id \\ Tedi Priatna \\ Faculty of Tarbiyah and Teacher Training \\ UIN Sunan Gunung Djati \\ Bandung, Indonesia \\ tedi.priatna@uinsgd.ac.id
}

\author{
Aan Hasanah \\ Faculty of Tarbiyah and Teacher Training \\ UIN Sunan Gunung Djati \\ Bandung, Indonesia \\ aanhasanah@uinsgd.ac.id \\ Payiz Zawahir Muntaha \\ Faculty of Tarbiyah and Teacher Training \\ UIN Sunan Gunung Djati \\ Bandung, Indonesia \\ Payizzawahir@uinsgd.ac.id
}

\begin{abstract}
This study aims to: 1) know the inheritance of local cultural values in Kampung Adat Pulo Garut (Kampung Adat); 2) know the model of character inheritance in Kampung Adat; and 3) know the values of characters that can be implemented as a base forming the character of the nation. So these findings can be useful to educational institutions. This study uses case study method, in Kampung Adat, data collection techniques using indepth interviews, observation, and literature study. The results of research, include: first, the reality of education in the inheritance of local wisdom values in the village, through the process of acculturation, socialization, and internalization. Second, the character inheritance model that is able to preserve and maintain the traditional values ancentral heredity consistently. The model of character education inheritance in the village as follows: 1) focus, derived from the doctrine of the Qur'an and Sunnah that aims to gain ridha and closeness to Allah SWT; 2) Procedures, using direct intructional model, by modeling method, habituation, counseling, giving attention, and rule enforcement; 3) The social system by means of prohibition, rule enforcement, and religious tolerance; and 4) Supporting factors, internal factors, strong firmness to rules and external factors: tourism rides. Thirdly, the character values that can be implemented as the basis for the nation's character formation are: religious, sociable and tolerant, consistent with rules, simplicity and independence, hardworking, forbearing, ikhlas, and democratic.
\end{abstract}

\section{Keywords-Acculturation; Socialization; Culturalization}

\section{INTRODUCTION}

This research started from the faded values of the nation's character that has been initiated by the founders of this nation. As examples of bullying cases conducted by learners in recent years, have tarnished the world of education. Other deviant behaviors that do not reflect on the nation's culture such as brawl, free sex, abortion, and also start signs of leaving the local culture to shift to western culture (such as secularism, pragmatism, and hedonism). These cases are what Durkheim calls an anomie. Preventive action through character education is an effective medium so that it does not happen again [1] [2]. Educational institutions are a very strategic place in the process of cultivating character education [3] [4] [5]. Because children longer interact and socialize in the environment. For that school has a large capital in the cultivation of character education. To that end, character education must be implemented by using learning strategies that are in accordance with the principle on meaningful, integrative, value based, challenging, and active [6].

Character-based local culture education is an educational model that has high relevance to the development of life skills and skills empowerment as well as local potential in each region as its foundation [7] [8]. Local culture-based education is an education that always teaches the learners to keep and close to the real situation [9]. Therefore, character education based on local wisdom becomes a necessity. For local cultural wisdom has a very significant role in building and maintaining the identity of this nation. Especially in protecting learners against the negative impacts of globalization, minimizing conflict, and preserving the local culture of the nation [9] [10] [11] [12] [13] [14]. Especially in 2000, Lawrence Harrison and Samuel Huntington, once assumed that cultural values greatly affect the progress and decline of civilization of the nation and people [15].

Kampung Adat is one of the villages that still can maintain the cultural values inherited by the ancestors. This can be seen from the people there, led by the Interpreter Lock (Kuncen) still preserve and maintain the norms of normal customs that apply there. There are some habits that are made as normal, until now still held firm, in the village, among others: 1) Prohibited pilgrimage and receive guests on Wednesday night (Tuesday night) until Wednesday, because the day is used to teach religion. And even the local people were not allowed to work hard; 2) The roof shape and the composition of the house 
must be mamanjang (jolopong or jure); 3) Do not hit big gongs; 4) In one house there should be no 2 families; 5) Those who are allowed to stay at home are women, and can be inherited to girls, whereas for married boys, a maximum of 2 weeks, must leave the village adat; 6) It is prohibited to keep large four-legged animals, such as goats, buffaloes, cows and so on; and 7) Religious rituals, especially in the month of Maulud, should be held for the month, with the ritua religious rank consisting of: 1 Maulud welcomes the month of maulud, 12 mauludan celebrations, 13-4 maulud bathing the destruction, at 12 o'clock, and the ritual is closed by having a mileuleuyankeun maulud month, as a marker of the end of maulud month [16].

Cultural values above, if not maintained and diwarikan, it will only be a historical record only. Local cultural values will survive, when implemented and internalized in everyday life. For that matter, researchers try to reveal and publish the cultural values that exist in the village. Indeed in reality, not many researchers reveal to the local cultural values that exist in Kampung Adat, whereas if observed that the culture in the village is one model can be used as an example, especially in maintaining and preserving and inheriting the local culture of the future generation. There is a fundamental difference to the research conducted by Muhamad Priyatna on the campus. The research conducted by him is character education based on local wisdom, so he concluded that the Kampung Adat Pulo community is still strong in maintaining the tradition of his ancestors. This is because they still cling to a very sacred norm [17]. However, researchers try to do research in the aspect of character inheritance model based on local cultural values on the campus. This study uses the theory of the model of cultural inheritance conveyed by Koentjaraningrat [18] discussing and Joyce [19]. While the paper, Yusuf Hidayat about the inheritance of multicultural values in the community of Kampung Gedang, Banjarmasin [20].

Character is a holistic blend of moral, ethics, and morals. Moral emphasizes more on human behavior or that action can be categorized as either bad or right-wrong [21]. Therefore, character education is called as a system of planting the values of character through aspects of thought, heart, taste, and initiative so that it can be implemented in everyday life. These aspects are a unity that is integrated with each other [22].

\section{METHODOLOGY}

This research is focused on the values of local wisdom in Kampung Adat Pulo Garut and as a participant is Juru Kunci (Kuncen). The approach of this research uses a qualitative approach, with some considerations as follows: first, the natural setting or the context of an entity. Second, the participant (instrument) in this research is human. Third, data collection techniques with observation, interview, and literature study. Fourth, the data collected in the form of words [23]. In accordance with the focus of research, the type of research is field description. Because researchers go to the field to conduct observations directly [23]. The method used in this study is case study method. Because researchers want to focus on research about the values of local wisdom in Kampung Adat Pulo Garut. So the research is done intensively (focus) and detailed (in-depth) [24]. Case studies involve case investigations, which may be defined as a restricted entity or study object, or separate for research in terms of time, place, or physical boundaries.

Data collection in this research for three stages, namely: a) Orientation stage. In this stage the researchers do a search on the internet to serve as an initial data source is in Kampung Adat Pulo Garut; b) Exploration stage. The researchers conducted data collection with observation, interview, and literature study; and c) The member-check stage. This stage is done in order to give all participants the opportunity to assess and consider the information that has been collected. This is done so that the existing data in the researcher becomes complete. In general, data collection techniques in this study is observation, structured interviews, and literature study. The three techniques are used interchangeably, repeatedly in accordance with the requirements and conditions of data collection. Data analysis techniques used in this study refers to the concept of Milles \& Huberman, the interactive model that classifies data analysis in three steps, namely: data reduction, display data, and conclusion (verification) [25].

\section{RESULTS AND DISCUSSION}

\section{A. Community Condition Kampung Adat Pulo Garut}

Kampung Adat Pulo is a village located on the island in the central of Situ Cangkuang. This village is located in the village Cangkuang, Kampung Cijakar, district Leles, Garut of West Java Province. Kampung Adat Pulo is located between Bandung and Garut which is $\pm 2 \mathrm{~km}$ from Leles and $\pm 17 \mathrm{~km}$ from Garut or $\pm 46 \mathrm{~km}$ from Bandung. Environmental conditions in this region have good environmental quality, cleanliness is maintained and also a good landscape.

The people of this village, formerly the majority of Hindu, then Embah Dalem Muhammad lived in this area, being forced to retreat from defeat when attacking the Belanda. The defeat of Embah Dalem Arif Muhammad did not want to return to Mataram, because of shame and fear of Sultan Agung. In the spread of Islam, Embah Dalem Arif Muhammad and his friends lived in the area Cangkuang, Pulo until he died and was buried in this village. He left 6 girls and one man. Therefore, in this village, there are 6 of the traditional house and 1 mushala is lined up and facing each other 3 houses on the left and right [16].

The total of houses in this village should not be increased or reduced, and so the people living in the house should not be more than 6 heads of households. A form of existing houses in the village must be roofed jure or jelopong (memanjang). If there are children who have adult is married, at least 2 weeks after that must leave the house and have to get out of the environment. But after his parents died, then the married is allowed to come in and replace the head of the family in the village [16]. 


\section{B. Education as Inheriting Values Local Wisdom in Kampung Adat Pulo Garut}

The process of inheriting cultural values is done through three processes, namely: the process of acculturation, socialization, and internalization [26] [18]. First, the process of cultural acculturation. The cultural acculturation process in the village is done by Kuncen [27]. Kuncen as a figure or elder and adat leader is the first person to do the process. Kuncen gained knowledge about history and norms in this village obtained from the results of meditation (wangsit). As he said when interviewed that "As we know that there is a real world and ghaib world. But I was never taught by a teacher and even I do not have a book to learn, while I learned directly through the alquran". Further Kuncen said that "I was told by my parents through the ghaib world, not the dhahir world. My parents asked me "Son, bejakeun ka jalma nu aya dihareup mun kudu sing bukti, mun maca sing kaharti, mun nyarita kudu sing nyata, dek diteang kamana, dek diudag-udag kamana? Anjeun kudu merhatikeun nu aya dina jero anjeun nyalira sanes nu batur".[16].

Second, the process of socialization is a process to introduce (socialize) the culture so that they understand and live and run the culture in everyday life [27]. After Kuncen gained knowledge from the teacher, through meditation, Kuncen socialized to the peoples of this village. The process of socialization is done, aiming to preserve the ancestral culture to the next generation. For example, the prohibition in this village, if not properly socialized, then there will be citizens who violate the ban [16]. The prohibition applies not only to the villagers, but to all the people around the village, and despite to the visitors (tourists).

Third, the process of internalization is the process of appreciation of value, so it becomes a belief in the truth of the value is embodied in everyday behavior [27]. If all the villagers, the surrounding community, and visitors (tourists) know everything that should be avoided (prohibition), then they will do the process of anticipative (prevention). Anticipatory, at least they have believed or at least respect the teachings or restrictions prevailing in this village. Being recognized or not believing or even respecting it is a process of internalizing cultural values.

\section{Character Education Model in Kampung Adat Pulo Garut}

The model of cultural inheritance is a guideline in the process of implementing and implementing character to others, so that they can implement it in everyday life. The model theory of inheritance of cultural values in this study using a model developed by Bruce Joyce, Marsha Weil and Emily Calhoun. Model inheritance of cultural values is a pattern that can be used to create an education, so that it can be passed on to future generations. There are four things that Joyce invented in modeling [19] [28].

Based on the results of interviews that the Kampung Adat Pulo has a system of inheritance of cultural values that are able to preserve and maintain the values of ancestral tradition from generation to generation with consistent. This is evident from the fact that the people of the village to this day remains consistent in maintaining and caring for the tradition is strong.
The model inheritance of local cultural values as a process of preserving and preserving the traditional values that exist in the village community as follows:

1) Focus: Focus is the main aspect of the model. Focus is a system that refers to the terms of reference in the development of a model. Development of the reference is the purpose and assumptions. Inheritance goals and environmental aspects will essentially shape the focus. The main purpose of inheritance of cultural values is to preserve and preserve the ancestral culture and earn the pleasure of Allah SWT. The source of cultural value possessed by Kuncen is derived from the teachings of the ancestors, through meditation (wangsit) [16]. The core of the teachings that Kuncen conveys to the people is to hold on to the source of the first and main Islamic teachings, namely the Qur'an and Sunnah, so that we will get the pleasure of Allah SWT. As the narrative from Kuncen states that "With the existence of 6 houses and 7 with the mushala it is a symbol of history," said Sunan Wirawijaya, the meaning of this traditional kampung symbol is that we must Tafakur to Allah, ask something only to Allah. "." [16]

Learning from the pattern of inheritance and education in the Kampung Pulo, character building should touch on the aspect of transcendence awareness (Ilahiyyah) learners, the values that originate in the teachings of religion [29] (30). Because religion will be a solid foundation in preventing the negative impact of globalization. This is a form of acculturation and internalization of local cultural values with values Ilahiyyah. In order to overcome the various crises that occur in the world of education, the educational institutions must be able, to perform the process. So it will become habituation (character). Moreover, the nation of Indonesia is a nation that the majority of the population is Muslim. Therefore, the foundation of inheritance of character values based on the source of Islamic teachings becomes a necessity.

2) Syntax: Syntax is a model stage that has a description of operational steps (applicative). The activities are arranged based on various stages clear so as to facilitate the achievement of educational goals. Syntax is the composition of the whole learning program. As the results of interviews and observations, the process of inheriting cultural values in Kampung Adat, using direct instructional model. As Kuncen said that "the father was never taught by a teacher, father did not have a book to study, the father studied directly through the Qur'an". And "the father is only told by the parents through the unseen nature, not the natural dhahir" [16]. This means that the process of transfer of knowledge and value, directly from the teacher who came from the unseen nature, especially Mama Arif Muhammad. The process of knowledge transformation, often done near the tomb of Mama Arif Muhammad. According to Kuncen, "The ancestors of this village gathered there, every Tuesday night Wednesday. Hence, on Tuesday and Wednesday are not allowed to make a pilgrimage to eat Mama Arif Muhammad "[16].

Based on the above results, the researchers made a conclusion that the process of inheritance of cultural values in the village conducted by Kuncen, using direct instructional 
model. Because the learning patterns that use direct learning will be able to maintain the integrity and expand knowledge and social institutions, especially the interaction directly, so as to provide a very meaningful experience for educators and learners [31]. After obtaining knowledge from the teacher, Kuncen immediately transfers to the whole village community, by way of oral, exemplary, habituation, advice, giving attention, and enforcement of rules / norms (punishment).

3) Social Sistem: The nature of learning is an interactive relationship between educators and learners in one system. This third point leads to the role of educators and learners, especially the hierarchical relationships and norms of students who are considered good. For that, the social system is an important part of the model. Learning model describes the system in teaching about attitude, skills, and understanding, and others. According to Selo Soemardjan that a social system must consist of at least the norm, position and role of leader, and sanctions [32].

The social system of inheritance conducted in Kampung Adat was developed in a conducive atmosphere, in which the roles of educators (Kuncen) and learners (community), functioned in a hierarchical, disciplined, responsible, familial and tolerant way to the people who visited there. Kuncen acts as an adat leader who becomes a community facilitator to introduce norms, such as activities that should not be done in this village. In the rule enforcement in the village, Kuncen is very persuasive. As he said "There is a difference between customary law and government law, if the government's law is broken, then punishable. Whereas if the customary law, not directly given the punishment, but given time more " [16]. Kuncen is also very santu, in reproving the visiting community, for example, when there are visitors near the tomb that turned on the music on the phone, Kuncen can only rebuke with a polite greeting. Because according to Kuncen that the punishment of any violation of this village will come, but not directly"[16].

Likewise in terms of tolerance, in Kampung Adat is very tolerant. This is symbolized by the temple Cangkuang cultural site, which became a symbol of Hinduism, adjoining the dining founder indigenous villages, namely Mama Arif Muhammad, who notabane Muslims. As Kuncen said, "If we look at the genealogy of King Prabu Siliwangi, the Padjajaran does not distinguish between Hindus and Muslims. Here everyone is the same, Islam and Hindu are alive sauyunan (harmony) and together and there is no prohibition for every religion, then maybe we are pilgrimage to the temple and so do the pilgrimage to the grave "[16].

4) Support system: This fourth element aims to facilitate the educators and learners to achieve success in the application of learning models and strategies. Factors supporting the inheritance of local cultural values that exist Kampung Adat is divided into two parts, namely internal and external factors.

First, internal factors, namely the supporting factors in the village, such as their obedience or persistence in implementing the norms that act there. With full awareness and without any compulsion from anyone, including from Kuncen. This is evident from all the prohibitions be appointed in this adat village, by all peoples, both living and visiting, has never been violated. Although adat norms, when violated it is not directly punished. However, the beliefs of these adat villagers, when violating the norm, will happen to all residents living in the surrounding area. As mentioned from Kuncen, there were once people who violated the norm in this village, such as 1) "At that time, people from the district will carry out the entertainment, the pesta air. They have a big gong when the big gong is not hit, nothing will happen. Some of them there are unbelievers and hit big gong, alhasil the rostrum collapsed by the big air"; 2) "There has been a breach in this norm, where the man who came here married a woman from Banten, at that time there was an emptiness, so the man occupied the house first and finally there was a fire"; and 3) "When new boys are sunat, a lively party, when children are brought on convoy, and there is a violation of adat norms is beating big gong, resulting in great disaster, the big rain and the wind to affect children fell and died instantly" [16].

The Second one is external factors, namely the supporting factors that exist outside the adat village, such as the site Cangkuang Temple, as a cultural heritage. This adds, both economically and acculturation culture in this village. As the indication is many people without the village of Cangkuang, both around and without Garut, visit there. It is created by adat villagers to sell area along the come into the village. With the cultural heritage, this adat village, get access to the road is representative, satisfy electricity, and government care, and especially from the Tourism Office of Garut Regency becomes more respect to Kampung Adat Pulo.

\section{Cultural Values in Kampung Adat Pulo Garut as the Formation of Indonesian Nation Character}

Based on the results of interviews and observations, researchers found some values that are be carried and internalized in their daily lives. The ancestral cultural heritage, among others: religious, socialize with people and tolerant, consistent with rules (norms/consensus), living with simplicity \& independence, hardworking, forbearing \& ikhlas (heartfelt), and democratic.

First, religious aspect. The religiosity of Kampung Adat Pulo community, is very visible from both ritual behavior that they do. First, when harvesting. "When we do harvest in the fields or fields, then we immediately make a thanksgiving, making yellow rice. This ritual is done as a form of gratitude for something that has been eaten, which has been obtained, and that will be planted again in order to get better than what we planted before. The religiosity of Kampung Adat Pulo peoples, is very visible from both ritual behaviors that they do. First, when panen. "When we panen in the fields, then we immediately make a syukuran, making nasi kuning. We do this ritual in order to be grateful for what we have eaten, which we have received, and which will be planted again to get better from what we planted earlier, it is a sign of gratitude from the peoples of this adat village [16]. Second, the religious behavior of the village peoples is also evident from the celebration of Islamic holidays, especially in Maulud (Rabiul Awal) and Rajab. As Kuncen tells us that "This adat village continues the relics of our ancestors once as a ritual, the ritual here is taken Maulud: on the $1^{\text {st }}$ of Maulud, tawasyul accept in the moon; 
again on the $12^{\text {th }}, 13^{\text {th }}, 14^{\text {th }}$ of Maulud, the relic bathing heirloom on the $13^{\text {th }}, 14^{\text {th }}$ of Maulud was done at $12 \mathrm{p} . \mathrm{m}$ and after the month of Maulud held another blessing again, mileuleuyan of Maulud. And if Rajab, carried on every $10^{\text {th }}$ of Rajab [16].

Second, socialize with people and tolerant. Kampung Adat Pulo is located in the middle of the island, it does not mean that they are in social society, must be closed-door or intolerant. The people of this adat village, on the contrary, they always interact with the people in the village Cangkung. The interaction of adat villagers is visible from their behavior in the following matters: doing mutual assistance (kerja bakti), shalat Jum'at at the residents' mosques, and public and religious schools (recitations in the afternoons after returning from school), and so on [16].

While the village's tolerant attitude, visible from the following behavior of life: first, if there are villagers who died, then they are allowed to be buried in this adat village because the burial in this adat village is a public burial. As Kuncen said that "Most of the land from adat villages is used for public graves, not paid, if anyone from this adat village died in Jakarta, Bandung, it can be buried here" [16] . Second, the tolerant attitude of this adat village is very visible from the cultural sites that are here. With the temple, the Cangkuang Temple, symbolized by Hinduism, adjacent with the tomb of the founder of the village, Arif Muhammad, symbolized by Islam. That means that the tolerance of this adat villages has been from the ancestors. As the narrative from Kuncen states that "If we look at the genealogy of King Prabu Siliwangi, the Padjajaran does not distinguish between Hindus and Muslims".

Third, The consistency of Kampung Adat Pulo appears to enforce custom (norm) rules. Although the times are modern, however, this modernity does not shake their hearts to violate the norms they have already done. Suppose "A change to the size of a adat house, although the adat house has been renovated (there is a change), such as the size of a adat house, must be fixed or not allowed to build a jure-roofed house" [16]. Their reason is still consistent in carrying out the norm, "Then whoever will ngemumule the rules in this village, if not peoples of the adat villagers"[16]. The reason they are still consistent in running the norm, is no other than that "Then who else will keep the values taught by the ancestors and the rules that exist in this village, if not the citizens of this traditional village" [16]

For them, this norm is a rule that must be implemented and should not be violated, because if violated will have an effect, not only for those who violate but for all the people around. Although sanctions against this norm are different from government law. There is a difference between adat law and government law. If the law of the government is violated, it is immediately given a punishment, while the norm is violated, indirect punishment, but there is a time in advance. As Kuncen said, "There are people who want to excavate graves and according to this adat village it is not allowed, so at night the child dies, many people die for trying to excavate this land" [16].

Fourth, living with simplicity and independence. . Kampung Adat Pulo is a society that follows the pattern of life filled with homeliness and independence. This is evident from their principle, namely: seeng nyencreng, meaning that it is important to eat and drink. In order to meet their daily needs, they are farming and gardening (ngahuma). Even in ancient times, the people of this adat village cannot get out of the adat villages. All their needs are met only by farming and gardening. However, because the land for farming and gardening has been used for public burial, very few are doing farming and gardening activities. Now, this adat village is used as a tourist place, then their profession there is a switch to trade.

Fifth, hardworking, forbearing and ikhlas. Kampung Adat Pulo is a society that loves to hard-working, patient, and ikhlas. This can be seen from the activities they do in this place, such as 1) Although their place used as tourist attractions, but they do not demand excessive to the Tourism Office of Garut Regency. Whereas who take care and protect this adat land is a people adat villages. But now, because it has been used as tourist attractions and crowded, then taken over by the Department of Tourism. Instead of expecting from agency or others, it is better to sell around the entrance; 2) The people of this adat village are called patient, this is visible from the place they inhabit (lived) which is the inheritance of the ancestors be created a public burial.

Sixth, democratic. The democratic attitude in Kampung Adat Pulo is visible from the selection of Kuncen. The selection of Kuncen, should not be passed on to the child (the offspring) of who holds the present Kuncen. This means that the determination to become Kuncen is a person capable and responsible for the preservation of this adat village. It is as from Kuncen's remark that "Juru Kunci (Kuncen) served as long as he felt capable. And if he is not capable, then the position as Kuncen will be given to people who are able to and can implement this Juru Kunci" [16]. This illustrates the democratization of the people of this village. Because it is usually the Kuncen's continuation, it must come from the child or the offspring of Kuncen before (hereditary/nasabiyah), but here is not so. Whoever is capable and responsible, then he is entitled to be appointed as the Kuncen.

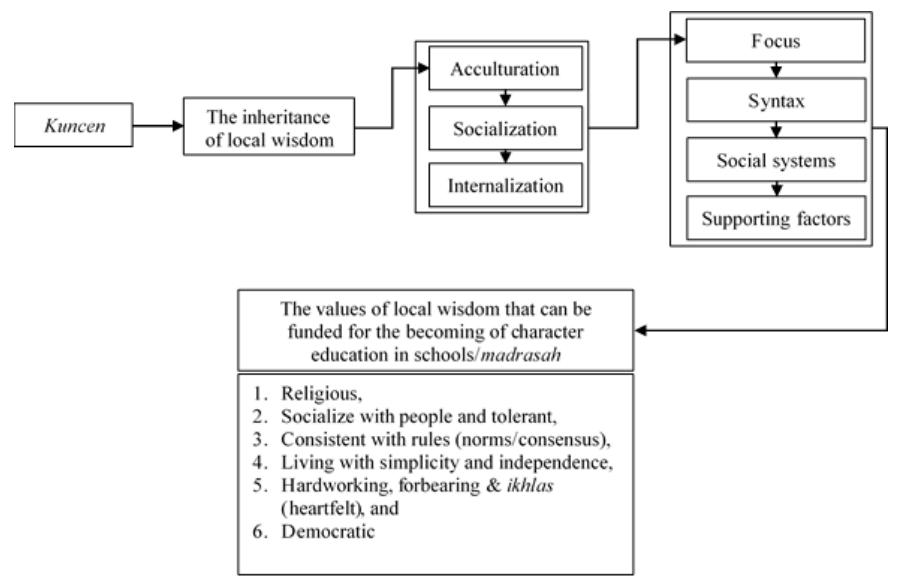

Fig. 1. Model of local wisdom inheritance in Kampung Pulo Garut. 


\section{CONCLUSIONS}

Based on the results of research and discussion can be concluded that the local wisdom is done consistently and passed down from generation to generation will still survive. This proved the inheritance of local wisdom values in Kampung Adat Pulo Garut, West Java, Indonesia. In the village, science and technology are remarkable, they still consistently run the ancestral culture. The values of local wisdom in the village can be used as a model for implementation as the becoming of character education in schools and madrasah (Islamic school).

\section{REFERENCES}

[1] Batlolona ML dan JR. Full Day School dalam Pembentukan Karakter Siswa SMKN 13 Kota Malang. J Ilmu Sos dan Hum. 2017;6(1):26-33.

[2] Abduljabar B. Memperkokoh Pendidikan Karakter melalui Aktivitas Jasmani Berbasis Nilai. J Pendidik Karakter. 2014;IV(1):97-107.

[3] Barus G. Menakar Hasil Pendidikan Karakter Terintegrasi di SMP. J Cakrawala Pendidik. 2015;2(2):222-33.

[4] Lickona T. Educating for Character: How Our Schools Can Teach Respect and Responsibility. Bantam: Bantam Trade Paperback Ed edition; 1992.

[5] Ramdhani MA. Lingkungan Pendidikan dalam Implementasi Pendidikan Karakter. J Pendidik. 2014;8(1):28-37.

[6] Harahap ZH. Pendidikan Karakter Berbasis Nilai Moral dan Nilai Kebangsaan. Pros Semin Nas Tah Fak Ilmu Sos Univ Negeri Medan Tahun 2017. 2017;1(1):407-10.

[7] Rukiyati Sugiyo dan, L. Andriani Purwastuti. Local Wisdom-Based Character Education Model in Elementary School in Bantul Yogyakarta Indonesia. Sino-US English Teach. 2017;14(5):299-308.

[8] Nadlir. Urgensi Pembelajaran Berbasis Kearifan Lokal. J Pendiidikan Agama Islam. 2014;2(2):300-30.

[9] Istiawati NF. Pendidikan Karakter Berbasis Nilai-nilai Kearifan Loka Adat Ammatoa dalam Menumbuhkan Karakter Konservasi. Cendekia. 2016;10(1):1-18.

[10] Suwardani NP. Pewarisan Nilai-nilai Kearifan Lokal untuk Memproteksi Masyarakat Bali dari Dampak Negatif Globalisasi. J Kaji Bali. 2015;5(2):247-64.

[11] Fajarini U. Peranan Kearifan Lokal dalam Pendidikan Karakter. SOSIO Didakt Soc Sci Educ J. 2014;1(2):123-30.

[12] Suprapto. Revitalisasi Nilai-nilai Kearifan Lokal bagi Resolusi Konflik. Walisongso. 2013;21(1):19-38.

[13] Yunus R. Transformasi Nilai-nilai Budaya Lokal sebagai Upaya Pembangunan Karakter Bangsa. J Penelit Pendidik. 2013;13(1):67-75.
[14] Santosa P. Kearifan Budaya dan Fungsi Kemasyarakatan dalam Sastra Lisan Kafoa. METASASTRA; J Penelit Sastra. 2012;5(1):67-82.

[15] Huntington LEH dan SP. Kebangkitan Peran Budaya; Bagaimana Nilainilai Membentuk Kemajuan Manusia. Jakarta: Pustaka LP3ES; 2006.

[16] Sanjaya A. Kondisi Masyarakat dan Nilai-nilai Kearifan Lokal di Kampung Adat Pulo Garut. 2017.

[17] Priyatna M. Pendidikan Karakter Berbasis Kearifan Lokal. Edukasi Islam J Pendidik Islam. 2016;5(10):1311-36

[18] Koentjaraningrat. Manusia dan Kebudayaan Indonesia. Jakarta: Djambatan; 2010

[19] Brouce Joyce, Emily Calhoun and DH. Models of Teaching; Tools for Teaching. Boston USA: Pearson Education; 2009.

[20] Hidayat Y. The Inheritance of Multicultural Values in the Community of Kampung Gedang, Banjarmasin City, South Kalimantan. Adv Soc Sci Educ Humanit Res. 2018;147:364-7.

[21] Nasrudin, Herdiana I, Nazudi N. Pengembangan Model Pendidikan Karakter Berdasarkan Sifat Fitrah Manusia. J Pendidik Karakter 2015;(3):264-71.

[22] Zuchdi FY dan D. Nilai Pendidikan Karakter Cerita Rakyat Suku Pasemah Bengkulu dan Relevansinya sebagai Materi Pembelajaran Sastra. J Pendidik Karakter. 2016;VI(1):48-58.

[23] Moleong L. Metodologi penelitian Kualitatif. Bandung: PT. Remaja Rosdakarya; 2012

[24] Creswell JW. Educational Research: Planning, Conducting and Evaluating Quantitative and Qualitative Research. New Jersey: Pearson Education Inc.; 2012.

[25] Huberman MBM and AM. Qualitative Data Analysis: an Expanded Sourcebook. Thousand Oaks, CA: Sage Publications. 1999.

[26] Annisa Fitriyani, Karim Suryadi SS. Peran Keluarga dalam Mengembangkan Nilai Budaya Sunda (Studi Deskriptif terhadap Keluarga Sunda di Komplek Perum Riung Bandung). SOSIETAS; J Pendidik Sosiol. 2015;5(2):5-13.

[27] Bahasa TiPKP. Kamus Besar Bahasa Indonesia (KBBI) [Internet]. Pusat Bahasa. Jakarta: Pusat Bahasa; 2016

[28] Ridwan. Model Tadzkirah dalam Menumbuhkan dan Mengembangkan Nilai-nilai Karakter Anak Usia Dini. Efektor. 2017;1(29):44-53.

[29] Yusuf M. Pendidikan Karakter Berbasis Qurani dan Kearifan Lokal. KARSA J Sos dan Budaya Keislaman. 2014;22(1):53-66.

[30] Yusuf. Integrasi Pendidikan Karakter Berbasis Qurani dan Kearifan Lokal Bugis. J Stud Agama dan Masy. 2015;11(2):247-64.

[31] Saepudin J. Model Pembelajaran dalam Perspektif Ibnu Khaldun Resepsi terhadap Kitab Muqaddimah. EDUKASI J Penelit Pendidik Agama dan Keagamaan. 2015;13(2):222-38.

[32] Soemardi SS dan S. Setangkai Bunga Sosiologi. Jakarta: Jajasan Badan Penerbit Fakultas Ekonomi; 